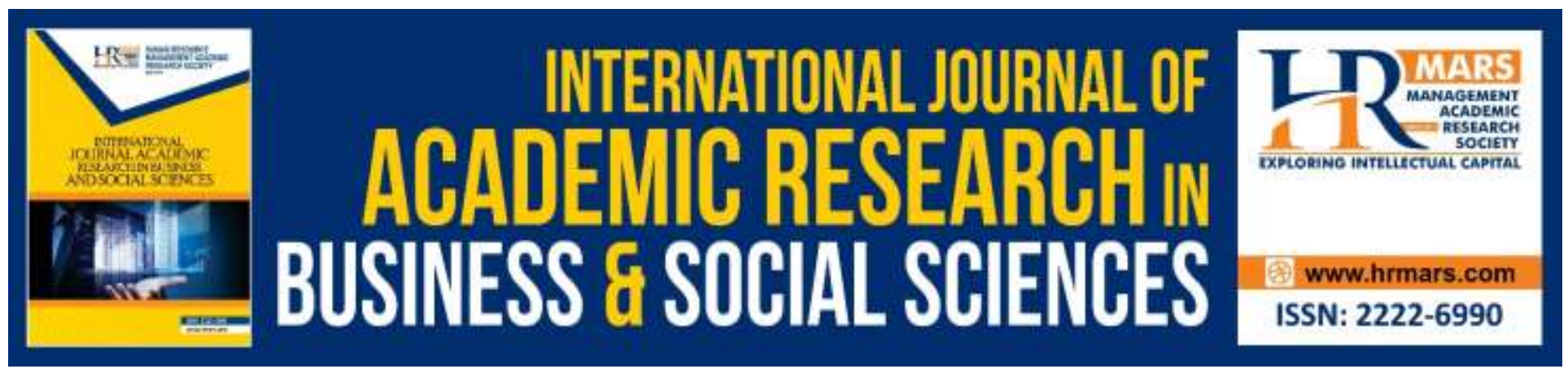

\title{
The Role of International Non-Governmental Organizations in Combating Terrorism in the Middle East
}

\author{
Adnan Tawfiq Wrikat, Anas Mohd. Yunus, Najihah Abd Wahid
}

To Link this Article: http://dx.doi.org/10.6007/IJARBSS/v10-i6/7307

DOI:10.6007/IJARBSS/v10-i6/7307

Received: 20 April 2020, Revised: 28 May 2020, Accepted: 01 June 2020

Published Online: 21 June 2020

In-Text Citation: (Wrikat et al., 2020)

To Cite this Article: Wrikat, A. T., Yunus, A. M., \& Wahid, N. A. (2020). The Role of International NonGovernmental Organizations in Combating Terrorism in The Middle East. International Journal of Academic Research in Business and Social Sciences, 10(6), 365-376.

Copyright: @ 2020 The Author(s)

Published by Human Resource Management Academic Research Society (www.hrmars.com)

This article is published under the Creative Commons Attribution (CC BY 4.0) license. Anyone may reproduce, distribute, translate and create derivative works of this article (for both commercial and non-commercial purposes), subject to full attribution to the original publication and authors. The full terms of this license may be seen

at: $\underline{\text { http://creativecommons.org/licences/by/4.0/legalcode }}$

Vol. 10, No. 6, 2020, Pg. 365 - 376

Full Terms \& Conditions of access and use can be found at http://hrmars.com/index.php/pages/detail/publication-ethics 


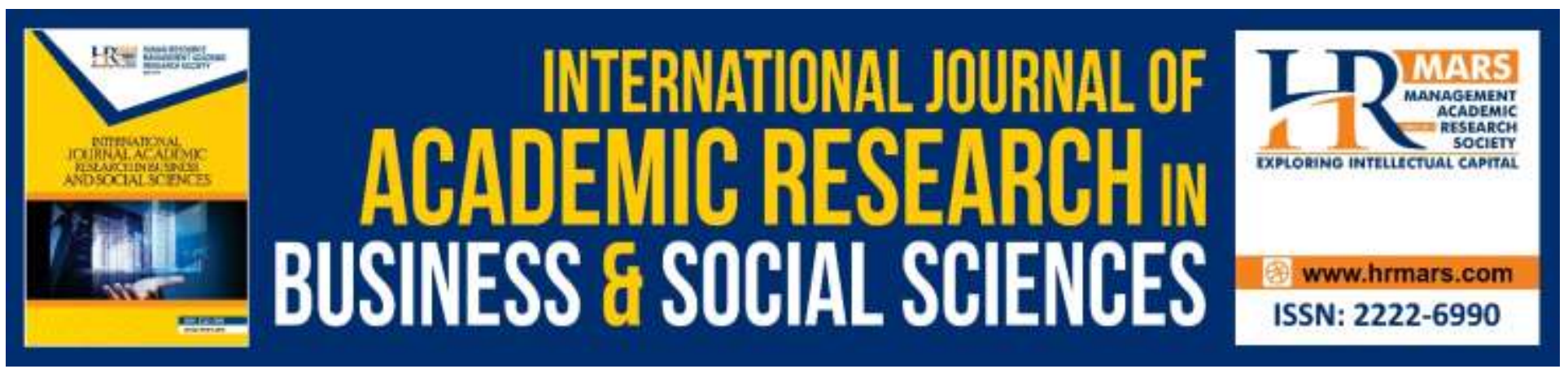

\title{
The Role of International Non-Governmental Organizations in Combating Terrorism in the Middle East
}

\author{
Adnan Tawfiq Wrikat, Dr. Anas Mohd.Yunus, Dr. Najihah Abd Wahid \\ Universiti Sultan Zainal Abidin, Malaysia
}

\begin{abstract}
Nowadays, among the biggest challenges faced by the majority of countries around the world, particularly that in the Middle East is on how to eradicate terrorism. This conceptual paper investigates the domestic institutional context in the Middle East on terrorism and the strategic role played by international organizations (INGOs) on this matter. Also, this paper looks into previous studies to examine what could be described as government tactics to influence INGOs in combatting terrorism. This study is significant as it connects the investigations on terrorism networks in the Middle East, by examining international NGOs and suggesting an alternative theoretical framework that covers the extent and nature of states' responses towards the threats from global terrorist networks.
\end{abstract}

Keywords: Terrorism, NGOs, INGOs, Middle East

\section{Introduction}

As demonstrated by the literature on international non-governmental organizations (INGOs) in international relations in the last recent years, most INGOs appear to congregate in the Western liberal democracies, as these countries grant them with the sought-after rights, freedoms, and resources (Keck \& Sikkink, 1998; Bob, 2005; Carter \& Terrence, 2004). In these countries, transnational links and boomerang effect have been used by International NGOs in influencing the practices and policies of governments and international organizations globally. Still, it should be noted that the number of operating INGOs in each country differs (Smith \& Weist, 2005; Reirnan, 2006). Furthermore, the terrorist attacks that occurred in the United States, United Kingdom and Spain that were linked to al-Qaeda, denote the strategic threat associated with the international nongovernmental organizations. The strategies and loci method of transnational advocacy networks have altered the new regulations especially in terms of outlook. This was for safeguarding the national security from a mounting transnational terrorist threat.

Europe, for instance, has been the favourite operational ground among the Middle Eastern terrorist groups. This was evidenced by 418 reported attacks from these groups from 1980 to 1989. As 
opposed to the European Marxist revolutionary or separatist terrorist groups, the Middle Eastern extremist groups were causing regional security problem to Europe. Additionally, the level of support that profited various groups in countries including 1ran, Iraq, Libya, Syria, Yemen, has become the most risky element of this Middle Eastern terrorist threat. For decades, the aforementioned countries have been producing fuel resources which had fallen into the hands of the Middle Eastern terrorist through bloodsheds. These resources were utilized by the terrorists in funding their activities. Given the problems of solving the various political conflicts and quarrels in the Middle East and the continuing attractiveness of Europe as a substitute battlefield for Middle Eastern terrorists (Phillips \& Michael, 2007).

The present paper examines the progression of national regulations on the responses of nongovernmental organizations (NGOs) and INGOs in several Middle East countries. Specifically, the present paper attempts to address the three questions below:

1. Has the domestic institutional context facing INGOs changed since 2000 after the dramatic attacks by international terrorists on Western liberal democracies?

2. What is the effect of new counterterrorism legislation on the organizational and strategic decisions of INGOs and hence their locations and operations since 2001?

3. Do the national regulations expound the current dissimilarities of INGOs across countries in terms of number, form, and activities?

The approach adopted in the present paper differs from that of past works on INGOs. Hence, rather than looking into the tactics applied by INGOs in influencing the governments, the present paper is focusing on

1- The regulatory environment in which these organizations operate, which can be regarded as the tactics utilized by government in influencing NGOs.

2- Studies on terrorist networks are reviewed in order examine the international NGOs.

3- This assures impartiality in the examination of INGOs while presenting the different theoretical lens in the scrutiny of global terrorist networks.

4- The examination of national regulations on INGOs and counterterrorism legislation will expand the INGO analysis from the third international, level of analysis in international relation to the incorporation of domestic factors that may improve the discovery of the location, type, and modus operandi of INGOs.

\section{Concept of Terrorism}

Terrorism is an infinite concept and it can describe various things. However, various relevant studies have established a basis in the delineation of the notion of terrorism. For instance, War on Terror which was announced by the US former President George Bush, had become the utmost priority of the USA after the September 11 attack in 2001. This so-called war had consequently transformed the domestic, national, and international policies of USA. Notably, the former US president George Bush had utilized the terms "terror," "terrorism," and "terrorist" thirty two times, but no definition was provided for each of these terms.

Best and Nocella (2004) discussed the term terrorism in their study by stating that all terrorism acts include violence, but not all violence involves terrorism was referred to actions. In defining terrorism, 
the authors indicated that it encompasses the institutional utilization of physical violence towards innocent individuals and animals for the advancement of the religious, ideological, political, or economic purposes of a person, organization, or state government. The definition provided by Best and Nocella shows that in terrorism, violence is directed at innocent individuals. However, in all contexts, the targeted individuals may not be wholly innocent.

Relevantly, Al-Thagafi (2008) described terrorism as the usage of either organized or random violence against innocent people with the aim of intimidating them for political purposes. Notably, the definition of terrorism provided by Al-Thagafi can be said to be limited considering that it provides no explanation on the nature of the perpetrators. Comparatively, the United States Department of Defense views the notion of terrorism as "the calculated use of unlawful violence or threat of unlawful violence to inculcate fear; intended to coerce or to intimidate governments or societies in the pursuit of goals that are generally political, religious or ideological." Apparently, the US Department of Defiance has presented a careful definition of terrorism. Nonetheless, it has sparked a question of whether the concept of lawful violence exists that civilians in the state can engage in such violence (Piri, 2016; Jackson, 2018).

Furthermore, the Arab Convention for the Suppression of Terrorism presented a new definition of terrorism (Al-Thagafi, 2008) as follows: any occurrence of act or threat of violence, irrespective of its purposes or motives, for the advancement of the individual or collective criminal agenda. In other words, terrorism is the process of seeking and creating panic among people, which may cause fear or harm to the people, and damage to the environment or public or private property, for the purpose of occupying the people or to jeopardizing the national resources (Al-Thagafi, 2008). The definition provided by the convention clearly describes the nature of terrorism from the Middle East region, and it sufficiently presents the ideology, nature, as well as mechanisms of terrorism. For both concepts of terrorism and commitment to counter-terrorism, this definition is essential.

In Shuhghart (2005), four unique characteristics of terrorism were presented as follows: political, planned, calculated, and systematic act. As understood, there are many definitions of terrorism provided by various scholars but the ones presented in this study can be referred in determining what constitutes terrorism (Cooper, 2001; Mohamed \& Alseyoufi, 2018). Fleischmann (2018) accordingly presented a dynamic viewpoint on this concept by stating that that an act is considered as an act of terrorism if done by others, but is considered as counter-terrorism if done by 'us.' Such view demonstrates the vagueness of terrorism as a concept, making it difficult to grasp. Equally, it is a subjective concept whereby an act that is regarded as a terrorism act to one may be regarded as an act of fighting for freedom to another (Dawoody, 2016; Fleischmann, 2018; Paul \& Bagchi, 2019).

\section{International Terrorism and the Middle East: A Review}

The September 11 event that happened in 2001 has intensified the global politics in the Middle East as the terrorist attacks were from a group called Al-Qaeda that emerged from this region. Since the last decade, wars and crises among regional states have become threats to the global peace and security, impacting the whole international system. At present time, threats to global security are perceived within the context of global terrorism (Saeed \& Johnson, 2016; Navias, 2017), and following the incident of September 11, a new method of dealing with terrorism has been introduced. At 
INTERNATIONAL JOURNAL OF ACADEMIC RESEARCH IN BUSINESS AND SOCIAL SCIENCES Vol. 10, No. 6, June, 2020, E-ISSN: 2222-6990 @ 2020 HRMARS

present time, terrorism is regarded as a global phenomenon that originated from the Middle East. As such, the link between the Middle East Region and the international terrorism issues should be examined (Barzegar, 2005; Bayar \& Gavriletea, 2018).

Barzegar (2005) perceived terrorism as a phenomenon that originated from the Middle East region. On the other hand, embracing a different viewpoint, Fahmy (2002) stated the need to redefine the concept of terrorism and security, by also taking into account the global threat of terrorism. Fahmy (2002) further stated that the 9/11 incident did not fully show a fresh security landscape for the Middle East considering that terrorism threat has been in existence in the region for decades. In support to Fahmy (2002), Shuhghart (2005) stated that Islamic terrorism can in fact be traced back to the Iranian Revolution in 1979. This unanticipated revolution involved attacks at the American Embassy in Tehran.

The Shi'a groups in Iraq, Saudi, Kuwait and Lebanon were inspired by the Khomeini regime, and they were receiving assistance from the regime as well. Through this regime also, the Hezbollah (Party of God) was formed. As mentioned in Shuhghart (2005), the Khomeini regime began spreading the new ideology around while also bringing serious security issue in the region. Another element that contributed to the rise of 1slamist terrorism was the Afghan War launched by Osama bin Laden. Afghan War provided the skills and experience related to terrorist to large number of members of non-Afghan militants (Shughart, 2005). Pertinently, Osama bin Laden was called a "terrorist entrepreneur" and he had become an inspiration to those members or the Arab nations who lost to the Soviet Union. In fact, the exit of the Soviet Union left Afghanistan in abundance with resources including money and artillery which are of value in funding the Islamic terrorism whenever there is opportunity for it (Shuhghart, 2005). The emergence of Islamic terrorism has sparked great terror in many countries all over the world.

In Bazergar (2005), the old and new terrorism that has been spreading from the Middle East was comprehensively deliberated, and the author had discussed its main factors. The author additionally mentioned the attempt of modern terrorism in spreading all throughout the world and that terrorism has always been around in all corners of the world. Somehow, in the new era, it appears that with its explicit definition, terrorism has benefited the international dimension, and within the international community, terrorism has become a significant subject. The September 11 incident is unquestionably a defining moment in terrorist activities. Relevantly, old terrorism comprised internal or regional dimensions that function within certain spatial and time domains, and this form of terrorism had lower negative impact on the international community. Contrariwise, the new terrorism goes beyond the national and regional boundaries as its impact are extensive, directly jeopardizing the global peace and security.

Wars and tensions among nations have threatened the international protection, and nations have been endangered by the unknown, sophisticated, und unconventional forces, with no easy solutions. Unlike old terrorism, new terrorism possesses no individual, nationalistic, or state-sponsored characteristics. As mentioned in Feinberg (2016), Asongu (2019) and Dinter and Yiiksel (D19), terrorism happens in various countries and terrorism has been fuelled by a global network. In this regard, the Middle East has been dubbed as the hub of new terrorism propelled by the Sunni Islamic 
INTERNATIONAL JOURNAL OF ACADEMIC RESEARCH IN BUSINESS AND SOCIAL SCIENCES Vol. 10, No. 6, June, 2020, E-ISSN: 2222-6990 @ 2020 HRMARS

radicalism, represented by Al-Qaeda. There are three major aims of new terrorism namely, to destabilize international security, to de-legitimize western, and to create a new balance of power between the west and the Islamic World.

The US Department of State presented a Country Report on Terrorism in 2011, and as revealed by the report, the international efforts in promoting peace freedom, and democracy in the Middle East is being consistently undermined by the state sponsorship to terrorist groups (LaFree \& Dugan, 2016). This affirms the allegation made by Shuhghart (2005) that some countries have been providing sponsorship to terrorism acts since the 1990s. According to Bazergar (2005), this draws attention to the activities of other terrorist networks and organizations in the Middle East. Meanwhile, the Middle East countries are consistently being exposed to threats or terrorist attacks owing to a number of factors including weak governance, conflicts, collapsed state institutions, religious extremism, penetrable borders that enable free movement of people and illegal arms and the radicalization of vulnerable groups by more equipped ones. The problem is further exacerbated by poor socioeconomic conditions in these countries, creating a fertile platform for terrorism growth (Kirnunguyi, 2011; Makyian \& Ilostami, 2019).

The spread of terror is evidence in both the Middle East and in other continents. For instance, the activities of Al-Qaeda could be observed in Syria, Saudi Arabia, Yemen, Iraq, Afghanistan, Pakistan, and in Asian and Pacific regions as well. As reported in Alexander (2014) and Dawoody (2016), all these attacks were mainly planned and executed with the support of associate terrorist groups and similar motive-based terrorist groups. Equally, identifying the role of some countries in the organization, preparation, and execution of terrorist attacks is important, considering that some countries have been found to be supporters of terrorism through regular provision of supports towards international terrorism acts. For instance, Syria has been supporting terrorism since 1979, whereas Cuba has been supporting terrorism since 1982, while Iran has been sponsoring terrorism since 1984, and Sudan has been a sponsor state since 1993. As indicated by the US Department of State (2014), via the provision of funding and the needed arms and training to the terrorist groups, the aforementioned states promote the proliferation of international terrorism.

In the context of Iran, there has been a clear support towards international terrorism. This was evidenced through the country's expression of support towards terrorist groups by its officials, its influence on the politics of the Middle East, its power projection within the Arab nations and its jeopardy towards the Middle East peace process. In other words, Iran shows open support towards terrorism such as its support towards Hezbollah, Hamas and Al-Qaeda. Other countries also show support towards international terrorism but not as openly. These countries use proxy terrorist groups, as exemplified by Pakistan and its Inter-Services Intelligence (ISI). As indicated in Manni (2012), Salloukh (2017), Jackson (2018), and Hill (2018), the support towards the use of violence by Iran in achieving its political goals is indeed a threat to global peace. 
INTERNATIONAL JOURNAL OF ACADEMIC RESEARCH IN BUSINESS AND SOCIAL SCIENCES Vol. 10, No. 6, June, 2020, E-ISSN: 2222-6990 @ 2020 HRMARS

\section{National Regulations and INGOs Activities}

Change in national regulations on non-profit organizations including INGOs is examined in this study, but, this study will first discuss the trends in current regulation. Specifically, the types of applied law and their specific purposes are discussed in this section. In general, the institutionalism approach is used in attaining the incentives of governments in INGOs regulation and their (INGOs) likely responses. Within a given institutional environment, these new regulations either bring opportunities or constraints on the organizations' activities. The expectation is that the response of the organizations will be affected by these differential effects in addition to their principles, objectives, as well as their capability in adapting or leaving the country to reposition elsewhere. Hence, regulations can be utilized by states in structuring the behaviour of INGOs and in choosing certain types of organizations, while also encouraging others to change their activities or relocate beyond their borders (Moe, 1984; North, 1990; Dawoody, 2016; Hill, 2018).

National non-governmental organizations' regulations refer to the national legislation, decisions made by the court, guidelines and requirements of agency, and tax provisions. In general, the regulations encompass various specific rules that cover registration, legal personality, organizational form and legal identity, operation type, and dissolution specifications (Nato, 2016; Heiss, \& Kelley, 2017: Deloffre \& Schmilz, 2019). Usually, non-profit organizations include charities/public benefit organizations, associations, or even non-profit corporations.

Charities or public benefit organizations are generally faced with very tight rules and in fact these organizations are faced with the most constraining rules. These organizations have restricted mandates especially in regards to their political partisan activities, in addition to their obligation to fulfil exhaustive registration requirements (Rehrnan, 2018). However, such type of organization is given tax breaks or access to other government resources (Rehrnan, 2018). Meanwhile, some other types of organization are required to fulfil stringent financial statement standards imposed by the government, while also required to furnish information on their location, boards, and mission statement. However, their operations are not as limited when compared to those of charities or public benefit organizations.

It is common for INGOs in certain Middle East countries to be faced with stringent regulations, and this has caused these INGOs to relocate to other countries or regions. It was reported in Keck and Sikkim (1997), and Risse, and Sikkik (1998) that INGOs are not obliged to have their primary operations in the states whose political stands are in their favour. National biases within non-profit laws are in fact common. Somehow, this does not encourage or require INGOs to establish national branches, and according to Bloodgood and Trernblay-Boire (2008), this extends the accountability of INGOs while also tying them to be closer to countries. Moreover, there are countries with restricted campaign contributions and other political forms advocacy to nationals. This has intensified the motive for establishing local branches among non-governmental organizations. Somehow, rules and regulations are not necessarily constraints. In fact, within a given location, more regulations do not mean less interest of INGOs.

The mandate of NGOs determines their location of operation. For instance, those working on the UN or EN issues will have to be in Brussels or New York. In other contexts, regulations become an enabler 
rather than a restrictor, that is, the regulations assure NGOs access to institutions or resources providing that the stipulated conditions are fulfilled, as can be observed in the granting of competitions or contracts for foreign aid provision. Furthermore, as NGOs acclimatize to the fulfilment of niches formed by institutions and as INGOs make the efforts in finding and operating in their most favourable institutional environment, isomorphism can eventually occur (DiMaggio \& Powell, 1983; Harnrnack \& Heydeman, 2009; Jibril \& Yakubu, 2017).

\section{Counterterrorism Regulations and INGOs}

The new legislation on counterterrorism is an exogenous shock which has changed INGOs in terms of their operational institutional landscape. Meanwhile, the potential civil societies established over many years have provided a fitting functioning system within a domestic political context for survival. However, among scholars and practitioners, there have been concerns towards the inadvertent consequences of new counterterrorism legislation on local NGOs and the civil society in general (Bloodgood \& Trernblay-Boire, 2008; Hammack \& Heydeman, 2009; Dawoody, 2016).

Accordingly, the present section looks into the prospective counterterrorism measures in addition to the impact of such measures on INGOs and the civil society. Finally, this study will ascertain the difference between the measures of new counterterrorism and those of previous non-governmental, non-profit organization regulations. Further, this study will scrutinize the precautions taken by INGOs in adapting themselves in complying with these changes or in relaxing these new institutional constraints.

As reported in past works on international relations, the counterterrorism measures on civil society have twofold impacts (Sidel, 2006; Mertus \& Sajjad, 2008). First, scholars in this domain indicated that measures of counterterrorism legally limit activities and organizations while also increasing surveillance, and these may lead to the eradication of political space and social niches in which civil society thrived. Another point worth noting is the potential abuse of counterterrorism measures as a way to restrict and restrain freedoms, political organizations, and political debate in states (Mertus \& Sajjad, 2008; Heiss \& Kelley, 2017: Mohamed \& Alseyoufi, 2018).

Relevantly, Howell et al. (2008) indicated that actions that are used in restricting, monitoring, investigating, prosecuting, or impacting charities for the purpose restricting terrorist financing should also seek to preserve the autonomy and vitality that embody the charitable sector in democratic societies. The author further highlighted the need to balance between the society's desire to be free from terrorism and the society's desire towards having a vibrant, autonomous, and powerful charitable sector. Meanwhile, human rights NGOs are civil society organizations and there have been attempts among scholars to resist the restrictions imposed on the civil society on the grounds of counterterrorism. In this regard, advocating scholars argued that for a country, a healthy civil society functions as a defence from terrorism. Accordingly, the provision of better economic development, human security, and social freedoms by civil society organizations eradicates the interests of prospective terrorists towards terrorist activities, while also strengthening the state (Mertus \& Sajjad, 2008; Howell et al., 2008; Sidel, 2006; Howell, 2006). 
Somehow, state security issues are blurred in terms of the impact of counterterrorism measures on INGOs. INGOs are transnational players with varied motives such as concerns for own survival and embellishment, radical changes in state policies, government upheaval, and fundamental transformations in governance institutions, and for these reasons, INGOs can be a weighty threat to a government or state (DeMars, 2005; Bob, 2005; Kahn-Nisser, 2019). In fact, the difference between a terrorist organization and an INGO begins to become blurry at the individual organization level, and therefore, it is more likely that the legislation on counterterrorism will impact INGOs.

For policy makers and certain parties in the society, such impact may not be necessarily negative. In fact, stricter regulations imposed on INGOs may be viewed as beneficial by some, such as increased accountability. As such, the unintentional consequences of counterterrorism for INGOs in the attempt to curb the activities, organization, resources, and capability of terrorist groups need to be understood in order that balance could be achieved between the security of society and the survival of INGOs through the formulation of appropriate regulations (Howell \& Jude, 2006; Kahn-Nisser, 2019).

Various counterterrorism approaches have been implemented, including actions ranging from proactive and offensive to passive or defensive actions. Among these actions include actions that were taken to disrupt links through arrests made on the key members and through disallowance of access to the needed resources and locations, in addition to the increase in surveillance, monitoring, and enforcement of present regulations (Sidel, 2008; Enders \& Sandler, 1993; Arce \& Sandler, 2005). Among the techniques used as discussed in Arce and Sandler (1993) include satellite surveillance, information interception, military raids, covert attacks, pre-emptive strikes, and group infiltration. Equally, governments can build walls as a way to restrict access (civil defence) and this makes attacks more complicated (Arce \& Sandler, 2005; Posen, 2002). Also, in deterring terrorist attacks, governments can increase penalties and increase laws enforcement against terrorism at both the international and national level (Arce \& Sandler, 2005; Posen, 2002).

Counterterrorism can thus become a strategic game between terrorist organizations and between countries in an attempt to stop terrorism, considering that certain type of action carried out in one country is likely to cause terrorists to change their tactics or targets to targets with lower defences using anticipated acts (Arce \& Sandler, 2005). As such, it is important for countries to work hand in hand in coordinating their counterterrorism strategies to increase effectiveness while reducing cost (Posen, 2002; Arce \& Sandler, 2005).

\section{The research Contributions}

Fights against terrorism have been a long and arduous task, and the ensuing review and the analysis led to the deduction that terrorism is traceable to the Middle East. Nonetheless, the effects and casualties of new terrorism extend beyond this region with widespread complications and consequences on global peace. As such, the direct impact of terrorism on the Middle East countries deserves more attention, so that safety of the entire region can be achieved. Meanwhile, developed nations can also participate in the provision of adequate security equipment in dealing with such challenge. 
The majority of Middle East countries are dealing with problems that make them vulnerable to threats of terrorism. Among these problems are poverty, extremism, political and economic instability, penetrable borders, civil war caused by ethnic, racial, religious and ideological differences, violations of human rights and, insecurity. All of these problems increase the vulnerability of these countries, making them a good target for terrorist groups that are looking for a place to establish themselves. At the same time, the terrorist groups form alliances with terrorist networks that are present across countries to obtain funding, support, and supplies that will be used in terrorizing the masses.

\section{Conclusion}

In conclusion, the phenomenon of terrorism is now a global issue. As found thus far, it is not possible to fully eradicate terrorism; it can only be reduced. Based on the findings, countries can decrease and confine the spread of terrorism through the following: sharing of information on alleged or confirmed terrorist groups, intelligence gathering, achievement of political and economic stability, application of radical security measures, citizen reorientation focusing on the restriction of all forms of political, social and religious prejudice, eradication of fundamentalism and zealotry, and the application of communal security systems in fighting terrorism.

For the international community, there is a need to determine the most appropriate methods in sustainably dealing with state sponsors or terrorism. In combating international terrorism, the United Nations play a crucial role in assuring the use of proactive measures to adequately coordinate counterterrorism policy, particularly through the provision of monitoring and control towards the suspected individuals or groups travelling across national borders.

\section{References}

Al-Thagafi, A. (2008). Causes and Possible Solutions to the Middle East Terrorism.

Anderson \& Lisa. (2004). "Shock and Awe: Interpretations of the Events of September 11.

Arce, D., and Sandler, T. (2005). "Counterterrorism: A Game-Theoretic Analysis."

Arce, D., and Sandler, T. (2005). "Counterterrorism: A Game-Theoretic Analysis." Journal of Conflict Resolution 49 (2): 183-200.

Asongu, S. A. (2019). The persistence of global terrorism. Territory, Politics, Ciovernance, 1-22.

Baron, Barnett F (2004). "Deterring Donors: Anti-Terrorist Financing Rules and American

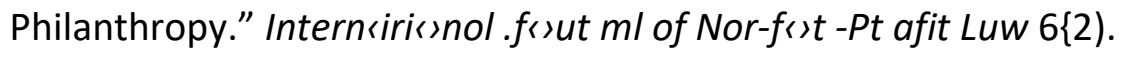

Barzegar, K. (2005). The Middle East and the New Terrorism. Journal on Science and World Affairs, 1 $\{2)$, pp. 113- 121.

Bayar, Y., \& Gavriletea, M. D. (2018). Peace, terrorism, and economic growth in the Middle East and North African countries. Qualit y \& Quantit y, 52(5), 2373-2392.

Best, S., and Nocella, A. (2004). Defining Terrorism. Animsil Lihrrition oM Philosoyh Bloodgorxl, Elizabeth, and Joannie Tremblay-Boire. 2008. "Race to the Bottom? NCO Policy Convergence and Divergence in the OECD." Paper presented at the Assrcitation for Research on $\mathrm{N}$ on-profit Organizations and Voluntar y Action (ARNOVA) Conference, Philadelphia, PA.

Bob, C. (2005). The Murk rtinp 's Rehellis sn.' Insurpents, Medici, and Intern tic snol Ar ti rem. New York: Cambridge University Press.C"ori|lik-t 2014 pp. 33-46). lloutled ge. 
INTERNATIONAL JOURNAL OF ACADEMIC RESEARCH IN BUSINESS AND SOCIAL SCIENCES

Vol. 10, No. 6, June, 2020, E-ISSN: 2222-6990 @ 2020 HRMARS

Carter, T. S. (2004). "Charities and Compliance with Anti-Terrorism Legislation in Canada: The Shadow of the Law." International .font rt 1 of Not-fot -Pt «) It Mn6\{3).

Cooper, H. (2001). Terrorism: The Problem of Definition Revisited. American Behavioural Scientist, 44(6), Februar y, pp.881-893.

Daw'oody, A. (2016). Terrorism in the Middle 1- asl: Policy and Adminislraliv'e Approac h. Eradicating Terrorism $t \mathrm{~mm}$ the Mid dle hast (pp. 3-28). Springer, Cham.

Dawoody, A. R. (2016). Terrorism in the Middle East: Polic y and Administrative Approach. In Eradicating Terrorism from the Middle East (pp. 3-28). Springer, Cham.

Deloffre, M. Z., \& Sc hmilz, H. P. (2019). 1NGO Legilimac y: Challenges and lies ponses. Dev'elopmenl Studies, 11\{1), 59-82.

DiMaggio, P. J., and Powell, W. (1983). "The Iron Cage Revisited: Institutional Isomorphism and Collective Rationality in Organizational Fields." American Sociological Review, 48: 147-160.

Dinar, H., \& Yuksel, S. (2019). Analyzing the possibilit y of violent conflict in the Middle East economies using determinants of global conflict risk index with an integrated fuzzy inulticriteria decision-making model. The impact of global terrorism on economic and Enders, Walter, and Todd Sandler. (1993). "The Effectiveness of Antiterrorism Policies: A Vector-Auto regression-Intervention Analysis." American Political Science Review 87(4): 829-844.

Fahmy, N. (2002). Implications of September 11 for Middle East Securit y, in Barletta M. (ed.) After 9,11: Preventing Mass-Destruction Terrorism and Weapons Proliferation.

Feinberg, M. (2016). Sovereigns $y$ in the age of global terrorism: the role of international organizations. Brill N ijhoff.

Fleischmann, J. (2018). The Root Causes of Terrorism in the Middle East and North Africa: Contradictions and Trends (Doctoral dissertation, University Honors College, Middle Tennessee State University).

Heiss, A., \& Kelley, J. (2017). Belw'een a rock and a hard place: International NGOs and the dual pressures or' donors and host gov'ernmenls. The Journal or Politic s, 79\{2), 732-741.

Hill, N. (2018). The kt fecl ct Terminal Levels of Education, National Economic Prosperity, and hates of 1s lamic Terrorism in the Middle 1-ast. Political Analysis, 19(1), 8.

Howell, J. (2006). "The Global War on Terror, Development, and Civil Society." Journal of International Development 18: 121-13S.

Jibril, M. L., Mohammed, 1. A., \& Yakubu, A. (2017). Social media analytics-driven counterterrorism tool to impros'e intelligence gathering towards combating terrorism in

Kahn-N, I. S. (2019). When the targets are members and donors: Analyzing intergos'ernrnental organizations' human rights shaming. The Review of International Organizations, 14(3), 431451.

Kimunguyi, P. (2011). Terroris $m$ and Counlerterrorism in 1-asl Africa, Global Terrorism llesearc $h$ Centre, Monash Unis'ersily, In sIralia.

LaFree, G., \& Dugan, L. (2016). Global Trends in Terrorism, 1970-2011. In P « « niid Makyian, S. N., \& loos lami, M. (2019). Political Stability, Corruplion, Democrac y, and Terrorism in the Midd ie last and Noah Africa. International Journal ct Business and adminstration.

Manni, N. (2012). Boko Haram: A Threat to African and Global Security. Global Security Studies, Call, Volume 3, Issue 4, pp.44-54.

Mertus, J., and Sajjad, T. (2008). "Human Rights and Human Insecurit y: The Contributions of US Counterterrorisin." Journal of Human Rights 7:1-23. 
INTERNATIONAL JOURNAL OF ACADEMIC RESEARCH IN BUSINESS AND SOCIAL SCIENCES

Vol. 10, No. 6, June, 2020, E-ISSN: 2222-6990 @ 2020 HRMARS

Mohamed, T. Z. F., \& Youfi, A. T. S. (2018). Evolution and impact of terrorism in the Middle East: implications for Egyptian travel and tourism. International Journal of Religious.

Nato, A. (2016). The European Public Prosecutor's Office between counter-terrorism and strengthening of the European citizens' safety. Civets E iiropa, (2), 317-338.

Navias, M. S. (2017). Finance warfare as a response to international terrorism. In War on Terrorism (pp. 323-345). Routledge. Nigeria. In ideas (Vol. 107). Nrtw orL in Intrt norionol Politic s. Ithaca: Cornell University Press. Occasional Paper, No. 8, Centre for Nonproliferation Studies, Montere y Institute of International Studies.

Oifice of the Coordinator for C'ounterterrorism (2014). Country Iteport on Terrorism 2013, July, US EieparImenl ct State Pu blicalion. Iletriev ed i'rom http://w'ww'.male.Nov/j/ct/rls/cm/2012/210017.htm, Data accessed on 29“' September.

Paul, J. A., \& Bagchi, A. (2019). Civil Liberties and Terrorism in the Middle East, North Africa, Afghanistan, and Pakistan. Annals of Operations Research, 275(2), 623651.

Phillips, Michael, R. (2007). “Final Audit Report - Screening Tax-Exempt Organizations' Filing Information Pros'ides Minimal Assurance That Potential Terrorist-Related Activities Are Identified." Trrisurv Imsper tot Genet ol [nr Two Admin istt oiirın.

Piri, S., \& Piri, A. Y. (2016). The Role of the US in Terrorism in the Middle East. J. Pol. \& L., 9, 31. political development: Afro-Asian perspectives, 155-166.

Posen, B. (2002). The Struggle against Terrorism: Grand Strategy, Strategy, and Tactics. Intern itionol See urit v 26(3): 39-55.

Reirnann, K. (2006). A View from the Top: International Politics, Norms, and the Worldwide Growth of NGOs. /nrrnnriono/ \'rudir.t (not trt 1v 50 \{1): 45-67.

Saeed, T., \& Johnson, D. (2016). Intelligence, global terrorism, and higher education: Neutralizing threats or alienating allies'? British Journal of Educational Studies, 64\{1),

Salloukh, B. F. (2017). Pers islent Permeabilily'/ llegionalis m, localism, and globalization in the Mid dle hasL Itoulled ge.

Shuhghart, W. (2005). An Analytical History of Terrorism, 1945 - 2000. pp. 1-65.

Sidel, Mark. (2006). "The Third Sector, Human Security, and Anti-Terrorism: The United States and Beyond." Voluntas 17: 199-210.

Smith, Jackie, and Weist, D. (2005). "The Uneven Geography of Global Civil Societ y: National and Global Influences on Transnational Association." .S"orrail Fun es 84: 621- Strategy Research Project, US Army War College, Carlisle BarracksTourism and Pilgrimage, 6(3), 86-106. 